\title{
THE IMPACT OF TRANSFORMATIONAL LEADERSHIP STYLE ON EMPLOYEE ENGAGEMENT: USING STRUCTURAL EQUATION MODELING (SEM)
}

\author{
Marwan Milhem ${ }^{1}$ \\ Faculty of Economics and Management Sciences, \\ Universiti Sultan Zainal Abidin, Malaysia. \\ (Email: si2050@putra.unisza.edu.my) \\ Habsah Muda ${ }^{2}$ \\ Faculty of Economics and Management Sciences, \\ Universiti Sultan Zainal Abidin,Malaysia. \\ (Email: habsah_muda@unisza.edu.my) \\ Khalil Ahmed $^{3}$ \\ IIUM Institute of Islamic Banking and Finance (IIiBF), \\ International Islamic University Malaysia. \\ (Email: khaleel8344814@yahoo.com)
}

Accepted date: $28-04-2019$

Published date: 08-07-2019

To cite this document: Milhem, M., Muda, H., \& Ahmed, K. (2019). The Impact of Transformational Leadership Style on Employee Engagement: Using Structural Education Modeling (SEM). International Journal of Modern Trends in Social Sciences, 2(8), 162-173.

DOI: $10.35631 /$ IJMTSS.280016

\begin{abstract}
Employee engagement helps businesses in attaining its goals. Employee engagement has been at the center of attention for human resource personnel and researchers who stated that employee engagement can be a key driver of an organization's business success. In Palestine only $11 \%$ of employees are engaged in work. Many researchers recently have found that transformational leadership style has an impact on the work engagement of employees. The population involved in this study includes 5281 full-time employees of which a sample of 328 employees was selected. Moreover, this study is considered to be the first local method to find and analyse the current causal effect of perceived transformational leadership style on employee engagement within the context of Palestine. The data was analysed using Confirmatory Factor Analysis (CFA), using Structural Equation Modeling (SEM). Analysis of Moments Structure (AMOS) was employed to answer the research questions and to test the hypotheses in this study. Results found that transformational leadership style has a significantly effect on employee engagement. Results show that transformational leadership is perceived to be more effective leadership in Palestine context. In conclusion, these study findings supported the hypothesis, answered the research question, and achieved the objectives of this study. Additionally; this study has successfully addressed the gaps found in previous literature review has contributed to the body of knowledge, as well as in providing useful implications to the industry in the context of Palestine and Middle Eastern Region.
\end{abstract}

Keywords: Structural Equation Modelling (SEM), Analysis of Moments Structure (AMOS), Confirmatory Factor Analysis (CFA) 


\section{Introduction}

Organizations seek to hire employees who can adapt themselves to the changes and are proactive, energetic, and creative when facing problems and challenges. There are two types of factors that determine employee engagement namely individual and external. Individual factors such as increased employee commitment, loyalty, retention, and employee satisfaction and productivity matters. External factors include increased customer engagement, satisfaction, retention, company reputation, and investor value (Kim et al, 2013; Kuntz and Roberts, 2014).

According to Hewitt (2014) stated that there is a shortage in promoting the important role of employee engagement by organizational leaders. However, Bakker (2011) suggested that the current study regarding leadership does not completely explain "how leaders influence their followers" and what techniques explain this influence.

According to a recent study of 1000 global organizations by Hewitt (2017), employee engagement peaked in 2015 at $65 \%$, but its gains were wiped away with a two-point drop in 2016 at $63 \%$. According to the above mention study there were some factors that affect the decline of employee engagement, such as populism (resentment toward foreign workers and open borders) which was caused by the prevalent Post Arab Spring in the Middle East and have a major impact on employee engagement due to new restrictions and pressure have been put on employees especially foreigners. According to the same study in Asia Pacific the overall engagement scores for employees in 2015 went from 65\% down to 62\% in 2016.

Aon's analysis reported that regional and country-specific political, cultural and economic differences drive regional variation in engagement.

Ghadi et al. (2013) showed that the transformational leadership style influences the work engagement of followers. According to them, there is a clear link between transformational leadership and employee engagement. Breevaart et al. (2014) indicated that the transformational leadership behaviour is considered as an important variable in the positive role affecting employee engagement. However, these studies examined the possible conditions that may further refer to the association of transformational leadership and employee engagement. Therefore; the researchers conducted a systematic review of the previous literature and found a literature gap in the relationships between transformational leadership, leader's emotional intelligence and employee engagement at global and regional levels particularly in Middle East. Thus, this study aims to address the aforementioned gaps and add to the richness of literature review of employee engagement and identify the causes of low levels of employee engagement in the context of Palestine since the employees in Palestine have challenges of being less prepared in terms of skills and competencies. Furthermore, they suffer from limited management support and participation in decision making (Khoury, \& Analoui, 2010).

\section{Literature Review}

\section{Transformational Leadership}

Various researches showed that transformational leadership skills successfully increase followers' motivation, commitment, performance levels, and have a beneficial connection with employee engagement. A broad array of definitions is revealed in the literature. The concept of leadership may vary across different disciplines, which makes it a universal 
phenomenon depending on the scope of the research (Holt \& Marques, 2012).

An early definition of transformational leader was developed by James Mac Gregor Burns (Burns, 1978). The author defined transformational leadership as a practice in which leaders use significant positive changes in individuals, groups, teams, and organizations through inspiration, vision, and the capability to motivate followers to exceed their self-interests for collective objectives.

Simola et al. (2012) describe transformational leadership as a sort of leadership in which relations among interested parties are planned "around a collective aim" in such a way that "transform, motivate, and enhance the movements and ethical desires of followers". Transformational leadership is a leadership style that pursues positive transformations "in those who follow" and that accomplishes preferred modifications through the "strategy and construction" of the organization (Geib and Swenson, 2013).

Kovjanic et al. (2013) proposes a multidimensional model in which transformational leaders positively influence followers' need for relatedness, autonomy, and competence. The results have shown that transformational leadership fostered "satisfaction of the needs for competence, relatedness, and autonomy, with competence and relatedness, needs satisfaction subsequently predicting followers' work engagement" (Kovjanic et al., 2013).

The transformational leader has characteristics that are expressively related with engagement according to scholars of the subject matter. Bass (1985) consistently links transformational leadership to employee engagement. Yukl (2013) conceptualizes to that transformation leaders motivate their followers to do more than what they are anticipated and requested to do. This goes with the engagement idea of additional part behaviour that engaged employees tend to display while accomplishing their jobs (Macey and Schneider, 2008).

Karen et al (2014) conducted a study to investigate the effect of internal communication on employee engagement. They interviewed public relations executives and found that the executives utilize an assortment of communication methods with employees such as face-toface communication. In addition, researchers recently found that transformational leadership styles have a beneficial linkage with employee engagement. Popli, \& Rizvi, (2016). stated that transactional leadership style has a progressive connection with employee engagement in which leaders motivate their subordinates and followers by appreciating and motivating them in lieu of task achievement. Ababneh (2015) examined the direct relationships between the antecedents (leadership and personal qualities) and employee engagement. He found that transformational leadership is linked to employee engagement in a positive way.

Breevaart et al. (2014) argued that transformational leadership plays and important role in forecasting employee engagement. A group of researchers (Schaufeli et al. 2006) examined the straight effect of daily transactional (provisional reward and management by exceptions/active) and transformational leadership styles on daily employee engagement. They used a survey in which they asked 61 naval cadets to answer a diary questionnaire (The 9-item UWES) over a course of 34 days while sailing. The results concluded that leaders who performed transformational behaviors and provided provisional rewards were more effective than those who do not. 


\section{Employee Engagement}

The definition of employee engagement is argumentative and there is a kind of disagreement among specialists and engagement researchers regarding its uniqueness from other wellfounded attitudinal concepts. Kahn (1990) discusses the latest explanation of employee engagement to appear in the academic literature. Kahn defines engagement as the "psychological presence of individuals who act of brief attachments and detachments during role performance". Kahn also maintains that "engagement is the joining of organizational members' selves to their work roles; during role performances work and shows themselves physically, cognitively, and emotionally". According to Kahn (1990), when employees perform their work and display all aspects of themselves (physical, emotional, and cognitive), then they are completely engaged, while disengaged individuals break away and distance themselves from their tasks. Schaufeli et al. (2002) define engagements as "a positive, fulfilling, work-related state of mind that is characterized by vigor, dedication, and absorption".

The basis of engagement models and concepts relates to two main areas of engagement research. First is the psychological theory of engagement (Kahn, 1990) and the second is job burnout model (Maslach and Leiter, 1997). For example, Kahn (1990) found that the psychological conditions (psychological meaning, well-being, and availability) show employee engagement in a significant way. Maslach and Leiter (2008) consider burnout model as the main antecedents of engagement and burnout six parts of work life (workload, control, reward, community, fairness, and values).

According to Abu Bakar, R. (2013), study in understanding the factors influencing employee engagement, there are three levels of employee engagement: individual, organizational and societal levels. The author places special emphasis two increasingly prominent perceptions: the possible role of religiosity empowering leaders' behavior, and High-Performance Work Practices (HPWP). The outcomes showed that there are three general subjects which play an important role in employees' engagement at work - empowering leadership behavior, an appropriate HPWP and an emphasis on religiosity. Moreover, the author found that managers and stakeholders should avoid nepotism and practice a transparent form of organizational culture.

\section{Transformational Leadership and Employee Engagement}

Previous research on employee engagement has empirically clarified the role of various antecedents in promoting employee engagement. Several researchers have investigated the effects of transformational leadership (Popli\& Rizvi 2016; Gözükara \& Simsek 2016).

Recently, there has been an increasing amount of literature on the effect of transformational leadership on work engagement. Gözükara \& Simsek (2016) published new papers study to examine the effect of transformational leadership on work engagement by focusing on the mediator roles of job autonomy and organizational identification. The study sample was 252 participants using a questionnaire and working in higher education. And it was analyzed using structural equation modeling. The results supported the study hypotheses, showing that transformational leadership had a positive effect on work engagement, and job autonomy and organizational identification totally mediated the relationship between transformational leadership and work engagement. The result specifically highlights the significant influence of job autonomy and organizational identification on work engagement within the context of leadership. 
Kesari \& Verma's (2018), study investigated the impact of transformational \& transactional leadership on employee outcomes in the perspective of steel industry. This seven-month study was conducted in a conceptual framework, and the samples consisted of 272 workers. The authors used SmartPLS 2.0 and structural equation modelling to analyze and confirm the conceptual framework. The results showed that a transactional leadership style has a negative impact on employee outcomes and managers used a transformational leadership style to improve employee outcomes. Moreover, results support that an employee is affiliated more closely with a transformational leadership style, rather than the transactional leadership style. Job demands, job resources, and job characteristics have also witnessed wide attention and were considered to be main dynamics affecting employees' decisions to engage (Bakker et al., 2014; Schaufeli and Bakker, 2004). Lately, the concentration of engagement research has been turned into investigating leadership styles, personality characteristics and organizational culture as possible antecedents of employee engagement (Arifin et al.; 2014; Handa and Gulati, 2014; Lee and Ok, 2015; Zhu et al. (2009). Moreover, given the lack of a joint agreement found between engagement practitioners and researchers about the meaning of employee engagement, the validity of those findings is still debatable.

Positive follower characteristics and transformational leadership were both positively linked with the followers' individual levels of work engagement as Zhu et al. (2009) found. More important, they found that these follower attributes moderated the association between work engagement and transformational leadership. An interesting, though not unexpected, finding was that work engagement was lower when the leaders perceived their followers as less favourable than the managers assessed themselves. Self- and other-ratings of transformational leadership often reveal discrepancies between the perceptions of leaders and followers (Bass \& Riggio, 2006). Zhu et al., (2009) revealed that a parallel effect for followership, which in turn, affected work outcomes.

The present study provides new insights into the specific mechanism by which leader's transformational leadership affects employee engagement where leaders who hold transformational leadership dimensions can influence followers' outcomes. The academic contributions of this study inform an enhanced appreciation and understanding of the importance of employee engagement among a set of antecedents and consequences. Findings of this study are evidence-based results based on a developed model that propose relationships between variables. In turn, this would extend the existing literature to better explain the place of employee engagement in the nomological network.

This study may benefit organizations and leaders at every level within organizations as it highlights the following findings: engaged employees make a significant variance to organizations' abilities to compete in an effective way and helped enhance meaningful business-unit performance by influencing several outcomes including lower turnover, lower absenteeism, higher employee loyalty and higher customer satisfaction. With this gap in knowledge, it can be concluded that transformational leadership has direct effect on employee engagement relationship. This study's conceptual structure is shown in Figure 1.

This conceptual framework has two key constructs: transformational leadership, and employee engagement. The transformational leadership is the independent variable and employee engagement as a dependent variable. The causal relationships among the variable are shown in the figure below. Therefore, this study presents the following hypothesis:

H1: Transformational leadership has a significant and direct effect on employee engagement. 


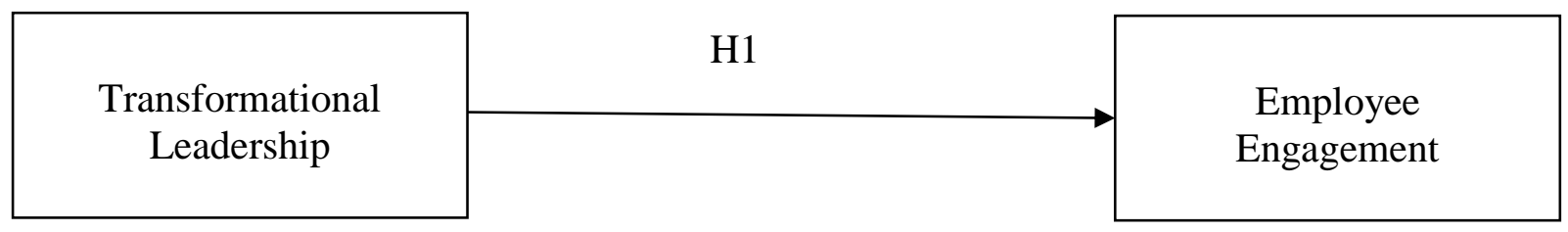

Figure 1 Conceptual Frameworks

\section{Methods}

\section{Sample and Procedures for Data Collection}

A sample is a subset of the target population which is used in order to answer the research questions. Additionally, the use of the entire target population as study respondents is faced with several difficulties such as inadequate research budgets, limited time factor and large geographical coverage of the respondents which can be mitigated by drawing of a subset of the target population as a true representative of the study population (Sekaran \& Bougie, 2016).

Hair et al. (2010) suggested once more that increasing the sample size could reduce the sampling error and recommend minimum sample sizes of 100 to 150 in order to ensure stable Maximum Likelihood Estimation (MLE). As a result, many authors recommend an appropriate sample size in a range of 150 to 400. According to Hair et al. (2010) a sample size of 100 is required for five constructs or less in a research framework as presented in table 1 For the meantime, this study followed (Hair et al. 2010) recommending for the minimum sample size as in table 1.

Table 1: Minimum Sample Size Required Depending on the Model Complexity

\begin{tabular}{|l|l|}
\hline $\begin{array}{l}\text { Model Characteristic (Number of latent constructs and } \\
\text { items) }\end{array}$ & $\begin{array}{l}\text { Minimum } \\
\text { Sample Required }\end{array}$ \\
\hline $\begin{array}{l}\text { 1. Five or fewer constructs. Each latent construct has more than } \\
\text { three items }\end{array}$ & 100 sample \\
\hline $\begin{array}{l}\text { 2. Seven or less latent constructs. Each construct has more than } \\
\text { three items. }\end{array}$ & 150 sample \\
\hline $\begin{array}{l}\text { 3. Seven or less latent constructs. Some constructs have less } \\
\text { than three items (just identified model) }\end{array}$ & 300 sample \\
\hline $\begin{array}{l}\text { 4. More than seven latent constructs. Some constructs have less } \\
\text { than three items (just identified model) }\end{array}$ & 500 sample \\
\hline
\end{tabular}

Due to the large sample size, the study utilized Structural Equation Modeling (SEM). According to Hair et al. (2010) Structural Equation Modeling requires large sample sizes.

A total of 439 questionnaires were distributed to the target population which included an additional $25 \%$ to cater for non-respondents. The numbers of questionnaires returned and entered were 328 , which represented a return rate of $75 \%$. The participants constituted a sample of full-time employees in ICT sector. The questionnaires were distributed with instructions to complete all the points properly. Cover letters were also distributed describing the objectives of the study, potential contribution, data collection, potential use of the research, and how confidentiality would be maintained to secure privacy.

\section{Measurement}

The measures used for the variables of the study are outlined as below: 


\section{Transformational Leadership}

The Leadership style scale assessed using the Multifactor Leadership Questionnaire (MLQ5X version; Bass and Avolio, 2004). The MLQ is broadly used and consists of 45 items. However, out of 45 times, only 16 items are dedicated to evaluating followers' own perceptions.

\section{Employee Engagement}

Employee engagement was measured by using the Utrecht Work Engagement Scale (UWES) developed by Schaufeli \& Bakker (2003).

\section{Results and Discussion}

\section{Exploratory Factor Analysis (EFA) for Transformational Leadership Construct}

The Exploratory Factor Analysis using the extraction method of Principal Component with Varimax (Variation Maximization) Rotation was performed on the 20 items measuring transformational leadership construct. The results in table 2 indicate that the Bartletts' Test of Sphericity is significant $(\mathrm{P}-\mathrm{Value}<0.05)$. Furthermore, the measure of sampling adequacy by Kaiser-Meyer-Olkin (KMO) is excellent since it exceeds the required value of 0.6 (Awang, $2012 ; 2015$ ). These two results (Bartlett's Test is significant and KMO > 0.6) indicate that the data is adequate to proceed further with the data reduction procedure.

Table 2: KMO and Bartlett's Test for TL Construct

\begin{tabular}{|c|c|c|}
\hline \multicolumn{3}{|l|}{ KMO and Bartlett's Test } \\
\hline \multicolumn{2}{|c|}{ Kaiser-Meyer-Olkin Measure of Sampling Adequacy. } & .929 \\
\hline \multirow{3}{*}{ Bartlett's Test of Sphericity } & Approx. Chi-Square & 3219.377 \\
\hline & Df & 351 \\
\hline & Sig. & .000 \\
\hline
\end{tabular}

The value of Cronbach's Alpha for each component was calculated to assess the internal reliability of the respective component in measuring the construct. The internal reliability or internal consistency indicates how strong the respective items are holding to each other in measuring the same construct. The value of Cronbach's Alpha should be greater than 0.7 for the items to achieve the internal reliability (Awang, 2012; 2015). The Cronbach's Alpha for the four components measuring the TL construct range between 0.841 and 0.952 . Thus, the items in all four components have achieved the required internal reliability since their Cronbach's values are greater than 0.7. (See table 3).

Table 3: Reliability Analysis for Each Component Measuring TL

\begin{tabular}{|c|c|c|c|}
\hline Name of Component & Number of Items & $\begin{array}{l}\text { Factor } \\
\text { Loading }\end{array}$ & $\begin{array}{l}\text { Cronbach's } \\
\text { Alpha }\end{array}$ \\
\hline \multirow[t]{8}{*}{ Intellectual Stimulation (TLS) } & \multirow[t]{8}{*}{8} & .798 & \multirow[t]{8}{*}{.952} \\
\hline & & .617 & \\
\hline & & .675 & \\
\hline & & .723 & \\
\hline & & .614 & \\
\hline & & .742 & \\
\hline & & .639 & \\
\hline & & .663 & \\
\hline
\end{tabular}




\begin{tabular}{|c|c|c|c|}
\hline \multirow[t]{5}{*}{ Individual Consideration (TLC) } & \multirow[t]{5}{*}{5} & .644 & \multirow[t]{5}{*}{.907} \\
\hline & & .698 & \\
\hline & & .752 & \\
\hline & & .645 & \\
\hline & & .715 & \\
\hline \multirow[t]{4}{*}{ Inspirational Motivation (TLM) } & \multirow[t]{4}{*}{4} & .608 & \multirow[t]{4}{*}{.907} \\
\hline & & .747 & \\
\hline & & .772 & \\
\hline & & .641 & \\
\hline \multirow{3}{*}{$\begin{array}{l}\text { Idealized Influence } \\
\text { (TLB) }\end{array}$} & \multirow[t]{3}{*}{3} & .766 & \multirow[t]{3}{*}{.841} \\
\hline & & .702 & \\
\hline & & .604 & \\
\hline
\end{tabular}

\section{Exploratory Factor Analysis (EFA) for Employee Engagement Construct}

The Exploratory Factor Analysis using the extraction method of Principal Component with Varimax (Variation Maximization) Rotation was performed on the 14 items measuring Employee Engagement (EE) construct. Table 4 shows that the Bartletts' Test of Sphericity is significant $(\mathrm{P}-$ Value $<0.05)$. Furthermore, the measurement of sampling adequacy by KaiserMeyer-Olkin (KMO) is excellent since it exceeds the required value of 0.6 (Awang, 2012; 2015). These two results (Bartlett's Test is significant and KMO $>0.6$ ) indicate that the data is adequate to proceed further with the data reduction procedure (Awang, 2012; 2015).

Table 4: KMO and Bartlett's Test for EE Construct

\section{KMO and Bartlett's Test}

Kaiser-Meyer-Olkin Measure of Sampling Adequacy.

892

Bartlett's Test of Sphericity

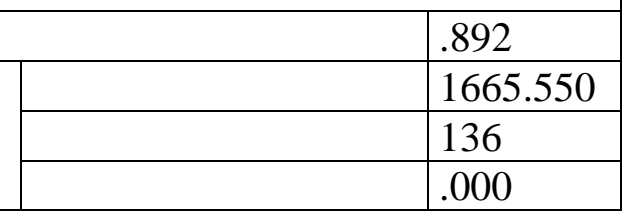

Results in table 5 show the Cronbach's Alpha for the three components measuring the EE construct where the value ranges between 0.829 and 0.949 . Thus, the items in all three components have achieved the required internal reliability since their Cronbach's values are greater than 0.7. (Awang, 2012; 2015).

Table 5: Reliability Analysis for Each Component Measuring EE

\begin{tabular}{|c|c|c|c|}
\hline Name of Component & $\begin{array}{l}\text { Number of } \\
\text { items }\end{array}$ & Factor Loading & $\begin{array}{l}\text { Cronbach's } \\
\text { Alpha }\end{array}$ \\
\hline \multirow[t]{7}{*}{ Dedication (ED) } & \multirow[t]{7}{*}{\begin{tabular}{l|l}
7 \\
\end{tabular}} & .866 & \multirow[t]{7}{*}{.949} \\
\hline & & .814 & \\
\hline & & .847 & \\
\hline & & .767 & \\
\hline & & .726 & \\
\hline & & .706 & \\
\hline & & .656 & \\
\hline \multirow[t]{4}{*}{ Absorption (EA) } & \multirow[t]{4}{*}{4} & .806 & \multirow[t]{4}{*}{.858} \\
\hline & & .842 & \\
\hline & & .757 & \\
\hline & & .721 & \\
\hline Vigor (EV) & 3 & .857 & .829 \\
\hline
\end{tabular}




\begin{tabular}{|l|l|l|l|}
\hline & .805 & \multirow{2}{*}{} \\
\cline { 3 - 4 } & & .624 & \\
\hline
\end{tabular}

\section{Confirmatory Factor Analysis (CFA) for TL and EE Constructs}

\section{CFA Assessment of Normality for Data Set}

Table 6 present the normality assessment for every item involved in the measurement model of TL and EE, accordingly. In the normality assessment for this study, the researcher observed the measure of skewness, which reflected the normality distribution for every item under each construct of TL and EE. Table 6 shows the values of skewness 1.0 or lower indicating that the distribution of data in this study was normal (Awang, 2015).

Table 6: The Assessment of Data Normality

\begin{tabular}{|l|l|l|l|l|l|l|}
\hline Variable & Min & Max & Skew & C.R. & Kurtosis & C.R. \\
\hline TLS6 & 1.000 & 10.000 & -.940 & -6.947 & 1.083 & 4.003 \\
\hline TLS5 & 3.000 & 10.000 & -.753 & -5.567 & .060 & .220 \\
\hline TLS4 & 3.000 & 10.000 & -.815 & -6.024 & .280 & 1.036 \\
\hline TLS3 & 3.000 & 10.000 & -.769 & -5.689 & -.053 & -.197 \\
\hline TLS2 & 3.000 & 10.000 & -.734 & -5.426 & -.062 & -.228 \\
\hline TLS1 & 1.000 & 10.000 & -1.072 & -7.929 & 1.342 & 4.962 \\
\hline TLM2 & 3.000 & 10.000 & -.794 & -5.871 & .146 & .540 \\
\hline TLM3 & 3.000 & 10.000 & -.641 & -4.740 & -.322 & -1.190 \\
\hline TLM4 & 3.000 & 10.000 & -.711 & -5.254 & -.189 & -.699 \\
\hline TLC3 & 1.000 & 10.000 & -.821 & -6.071 & .873 & 3.228 \\
\hline TLC4 & 2.000 & 10.000 & -.695 & -5.136 & .404 & 1.494 \\
\hline TLC5 & 1.000 & 10.000 & -.787 & -5.817 & .432 & 1.598 \\
\hline TLC1 & 1.000 & 10.000 & -.926 & -6.850 & .389 & 1.438 \\
\hline TLB5 & 1.000 & 10.000 & -.995 & -7.357 & .797 & 2.945 \\
\hline TLB3 & 1.000 & 10.000 & -1.064 & -7.866 & 1.205 & 4.456 \\
\hline TLB4 & 1.000 & 10.000 & -.825 & -6.102 & .504 & 1.864 \\
\hline EA4 & 1.000 & 10.000 & -1.049 & -7.757 & .720 & 2.660 \\
\hline EA3 & 1.000 & 10.000 & -.951 & -7.032 & 1.031 & 3.813 \\
\hline EA2 & 1.000 & 10.000 & -1.178 & -8.709 & 1.675 & 6.191 \\
\hline EV3 & 2.000 & 10.000 & -1.044 & -7.718 & 1.054 & 3.898 \\
\hline EV2 & 2.000 & 10.000 & -1.016 & -7.511 & .900 & 3.327 \\
\hline EV1 & 1.000 & 10.000 & -1.238 & -9.156 & 1.697 & 6.273 \\
\hline ED7 & 1.000 & 10.000 & -1.047 & -7.738 & .743 & 2.749 \\
\hline ED6 & 1.000 & 10.000 & -1.104 & -8.162 & .890 & 3.289 \\
\hline ED5 & 1.000 & 10.000 & -.999 & -7.386 & .649 & 2.400 \\
\hline ED4 & 1.000 & 10.000 & -1.118 & -8.265 & 1.236 & 4.568 \\
\hline ED3 & 1.000 & 10.000 & -.948 & -7.009 & .810 & 2.993 \\
\hline ED2 & 1.000 & 10.000 & -1.099 & -8.124 & 1.214 & 4.489 \\
\hline ED1 & 1.000 & 10.000 & -.944 & -6.978 & .910 & 3.364 \\
\hline & & & & & & \\
\hline
\end{tabular}


Figure 2 shows the structural model of transformation leadership and employee engagement, while the output from table 7 shows that when TL went up by 1, EE also went up by 0.575 . Besides, the regression weight is 0.575 and has a standard error .051. Dividing the regression weight by its standard error gives $z=0.575 / .054=10.683$. In other words, the regression weight estimate is 10.683 , with standard errors above zero. Moreover, the probability of obtaining a critical ratio of 10.683 in absolute value is less than 0.001 . In other words, the regression weight of TL when predicting the EE is significantly different from zero at the 0.001 level. Therefore, since the P-Value is lower than 0.05 , the above research hypothesis is accepted. This study concludes that Transformational leadership (TL) has a significant and direct effect on the Employee Engagement (EE).

Table 7: Path Analysis for Hypothesis

\begin{tabular}{|l|l|l|l|l|l|l|}
\hline Construct & PATH & Construct & $\begin{array}{l}\text { Beta } \\
\text { Estimate }\end{array}$ & $\begin{array}{l}\text { Standard } \\
\text { Error }\end{array}$ & $\begin{array}{l}\text { Critical } \\
\text { Region }\end{array}$ & $\begin{array}{l}\text { Significance } \\
\text { Value (P) }\end{array}$ \\
\hline TL & $<---$ & EE & .575 & .054 & 10.683 & $* * *$ \\
\hline
\end{tabular}

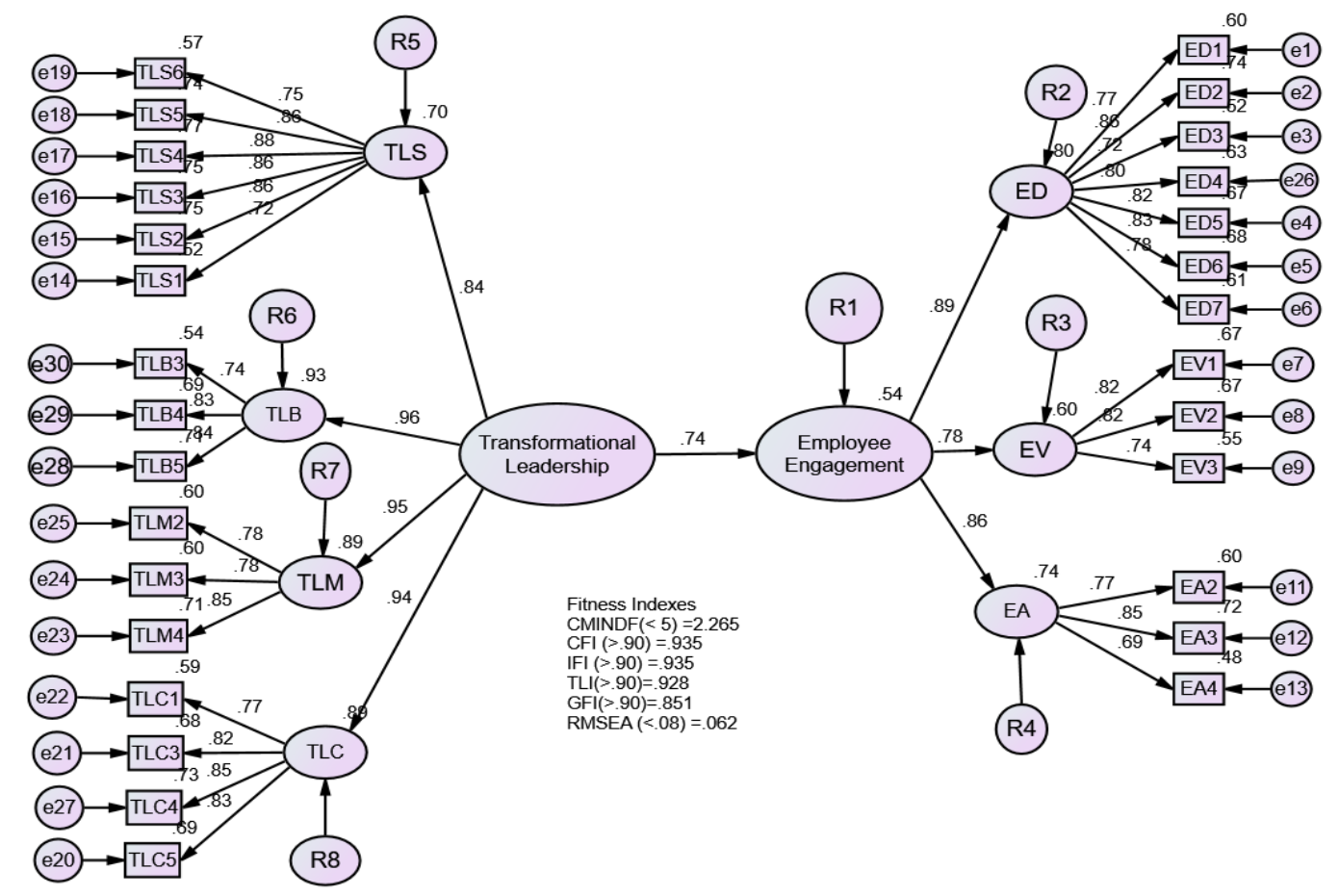

\section{Figure 2: Structural Model of Transformation Leadership and Employee Engagement}

The fit indices showed that the higher-order factor of the model fitted the data adequately. The fitness index for the measurement model was extracted and the result showed that the higher-order factor of the model fitted the data adequately: CMIN/DF=2.265, RMSEA $=0.062, \mathrm{CFI}=0.935, \mathrm{IFI}=0.935$. Under the "close fit" hypothesis (i.e., the RMSEA is no greater than 0.05 in the population), the probability of getting a sample RMSEA as large as 0.080 was 0.062 . The entire factor loading of the remaining items, as shown in Figure 1, had exceeded the required value of 0.6. Thus, the researcher could assume that the unidimensionality of the measurement model had been achieved. Hence, the researcher was satisfied with the obtained fitness index and the CFA procedure was completed at this stage before proceeding the structural modelling. The requirement for Composite Reliability (CR), 
and Average Variance Extracted (AVE) were achieved for all items factoring as: Transformational Leadership, $\mathrm{CR}=0.92$, and AVE was 0.76; and Employee Engagement, $\mathrm{CR}=0.88$, and AVE was 0.72 .

\section{Conclusion}

In conclusion, the results obtained_from Exploratory Factor Analysis (EFA) indicated that all components measuring the respective constructs possessed good internal reliability since all Cronbach's values have exceeded the threshold of 0.7 . Thus, the researcher would rearrange the items measuring every construct into their respective components accordingly and proceed with data collection in the field study. Results of Confirmatory Factor Analysis (CFA) in this study showed that there was a significant affect in the relationship between transformational leadership and employee engagement. In this regard, this study framework can be extended to further studies in another context other than ICT sector. This study has enhanced the literature and improved the organizational productivity of businesses globally in general and Palestine in particular. This study also presented the determination and understanding of the relationship between transformational leadership and employee engagement.

\section{References}

Ababneh, O. M. A. (2015). Conceptualizing and measuring employee engagement, and examining the antecedents of leadership styles and personality attributes (Doctoral dissertation, Auckland University of Technology).

Abu Bakar, R. (2013). Understanding factors influencing employee engagement: a study of the financial sector in Malaysia.

Arifin, A., Troena, E. A., Djumahir, \& Rahayu, M. (2014). Organizational culture, transformational leadership, work engagement and teacher's performance: test of a model. International Journal of Education and Research, 1(2), 1-14.

Awang, Z. (2012). Research methodology and data analysis. Penerbit UniversitiTeknologi MARA Press.

Awang, Z. (2015). SEM Made Simple: A Gentle Approach to Learning Structural Equation Modeling. Bandar BaruBangi, MPWS Rich Resources.

Bakker, A. B. (2011). An evidence-based model of work engagement. Current Directions in Psychological Science, 20, 265-269.

Bass, B. M. (1985). Leadership and performance beyond expectations. Collier Macmillan.

Bass, B. M., \& Riggio, R. E. (2006). Transformational leadership. Psychology Press.

Breevaart, K., Bakker, A., Hetland, J., Demerouti, E., Olsen, O. K., \& Espevik, R. (2014). Daily transactional and transformational leadership and employee engagement. Journal of Occupational and Organizational Psychology, 87, 138- 157.

Gözükara, İ., \& Simsek, Ö. F. (2016). Role of leadership in employees' work engagement: Organizational identification and job autonomy. International Journal of Business and Management, 11(1), 72.

Geib, P., \& Swenson, J. (2013). China: Transformational Leadership for Policy and Product Innovation. Advances in Management, 6(5), 3-10.

Ghadi, M. Y., Fernando, M., \& Caputi, P. (2013). Transformational leadership and work engagement. Leadership \& Organization Development Journal, 34(6), 532-550.

Hair, J. F. J., Black, W. C., Babin, B. J., \& Anderson, R. E. (2010). Multivariate data analysis Upper Saddle River: Pearson Prentice Hall.

Handa, M., \& Gulati, A. (2014). Employee engagement: does individual personality matter. Journal of Management Research, 14(1), 57-67. 
Holt, S., \& Marques, J. (2012). Empathy in leadership: Appropriate or misplaced? An empirical study on a topic that is asking for attention. Journal of business ethics, 105(1), 95-105.

Hewitt, A. (2014). Trends in global employee engagement report. Analysis included, 284, 2010-2012.

Hewitt, A. (2017). Trends in global employee engagement: Global anxiety erodes employee engagement gains. Talent, Rewards \& Performance.

Kahn, W. A. (1990). Psychological conditions of personal engagement and disengagement at work. Academy of Management Journal, 33, 692-724.

Karen Mishra, Lois Boynton, \& Aneil Mishra. (2014). Driving Employee Engagement: The Expanded Role of Internal Communications, International Journal of Business Communication, Vol. 51(2) 183-202.

Kesari, B., \& Verma, B. K. (2018). Does the Leadership Style Impacts on Employee Outcomes? A Study of Indian Steel Industry. Global Business Review, 19(6), 16021621.

Khoury, G, \& Analoui, F. (2010). How Palestinian managers cope with stress. Journal of Management Development, 29(3), 282-291.

Kovjanic, S., Schuh, S. C., \& Jonas, K. (2013). Transformational leadership and performance: An experimental investigation of the mediating effects of basic needs satisfaction and work engagement. Journal of Occupational and Organizational Psychology, 86, 543-555.

Lee, J., \& Ok, C. (2015). Drivers of work engagement: an examination of core selfevaluations and psychological climate among hotel employees. International Journal of Hospitality Management, 44, 84-98.

Macey, W. H. \& Schneider, B. (2008), 'Engaged in Engagement: We Are Delighted We Did It', Industrial \& Organizational Psychology, vol. 1, no. 1, pp. 76-83.

Maslach, C., \& Leiter, M. P. (1997). The truth about burnout. San Francisco Jossey-Bass.

Popli, S., \& Rizvi, I. A. (2016). Drivers of employee engagement: The role of leadership style. Global Business Review, 17(4), 965-979.

Schaufeli, W. B., Bakker, A., \& Salanova, M. (2006). The measurement of work engagement with a short questionnaire: a cross-national study. Educational and Psychological Measurement, 66(4), 701-716.

Schaufeli, W. B., Salanova, M., Gonz'alez-Rom'a, V., \& Bakker, A. B. (2002). The measurement of engagement and burnout: a two sample confirmatory factor analytic approach. Journal of Happiness Studies, 3(1), 71-92.

Schaufeli, W. B., \& Bakker, A. B. (2003). Test manual for the Utrecht Work Engagement Scale. Unpublished manuscript, Utrecht University, the Netherlands. Retrieved from http://www.schaufeli.com

Simola, S., Barling, J., \& Turner, N. (2012). Transformational Leadership and Leaders' Mode of Care Reasoning. Journal of Business Ethics, 108, 229-237.

Yukl, G. (2013). Leadership in Organizations (8th ed.). Pearson; Upper Saddlebrook, New Jersey.

Zhu, W., Avolio, B. J., \& Walumbwa, F. O. (2009). Moderating role of follower characteristics with transformational leadership and follower work engagement. Group \& Organization Management, 34, 590-619. 